\title{
The Existentialism of Feminist Extratextual Reality in Carol Maso's The Art Lover
}

\author{
Dr. Hazmah Ali AI-Harshan \\ Assistant Professor at the Department of Languages and Translation, Faculty of Education and Arts, University \\ of Tabuk, Saudi Arabia
}

\begin{abstract}
The postmodern text takes on the experimental challenge of confronting the lack of a center at the heart of language and dwelling in that void. Carol Maso accesses that void to confront issues of selfhood and authorship in her postmodern novel, The Art Lover (1990). Maso clearly understands that the conventional novel is predicated upon dominant ideologies of truth and identity, as well as on realism rather than existential reality. For her, it fails to represent truthfully the chaos of the world outside the authentic existential experience. She therefore consciously writes differently in order to tell some kind of truth about herself. Yet, as Dwight Eddins observes, by opting out of long-established literary conventions, postmodern authors like Maso are placed in a dilemma: "In humanizing this world, [s/] he lies; in trying not to lie [s/]he is threatened by incoherence and chaos" (205). Maso avoids the problem by fusing experimental writing with narrative conventions. Meanwhile, in her non-fictional writing, Maso asks, "What is a book and how might it be reimagined, opened up, transformed to accommodate all we've seen, ... been hurt by ... given ... taken away?" In using the inclusive term, "we", she recommends this experimental approach to other marginalized (oppressed or subjugated) authors. In the fiction itself, she indicates a means by which other marginalized female authors can emancipate themselves from the stultifying boundaries of fiction and the stereotypical identities /realities created for them by long-established literary convention. As an embodiment of this question about this project to re-imagine the book, The Art Lover, also invites marginalized readers to reread predetermined notions of a centered identity and accepted reality. Maso invites them to test her theories of the constructed nature of reality in their own lives. The multi-layered text of The Art Lover discusses both authorship and existential experience through the narratives of a fictional author, Caroline Chrysler, and that of the doubly fictional characters in the novel she is writing. Caroline distills something of her own fictional life into her fictional narrative both textually and through the insertion of a variety of intertexts in various media. But it is not just the fictional Caroline, who interpolates her life experience into the text of a novel. The real-world novelist, Carole Maso, does the same. Maso herself appears as a character in the fifth section of the novel, where she reveals that she is, in reality, dealing with the death of her best friend, Gary, who has died of AIDS. Arguably, Maso uses her novel - on a variety of levels - to carve out a space for herself where she can tell the "truth" of her lived experience as a woman and an author.
\end{abstract}

Keywords: Existential Experience; Experimental Writing; Narrative Techniques; Embedded Narrative; and Marginalized Female Authors.

DOI: $10.7176 /$ JLLL/84-04

Publication date: December $31^{\text {st }} 2021$

Postmodernism affords experimental female authors a way to say things, to express some approximation of the truth of their lives, in ways that were not theorized or foregrounded by earlier authors. In Feminism and the Postmodern Impulse, Magali Michael examines the "postmodern impulses" (5) of the experimental women writers. She emphasizes the notion that both feminist and postmodernist fiction "consider the range of possibilities that open up once Western metaphysics is problematized" and rely on aesthetic strategies that include "disruptions of traditional notions of subjectivity, character development, representation, language, interpretation, narrative, history, and binary Logic in general" (5). These aesthetic strategies take a variety of forms such as "the juxtaposition or collage of various types of texts or discourses ,...the active and self-conscious refusal to provide narrative authority or closure, and the appropriation and reworking of popular forms"(6). Thus, the fragmentation of the self, metanarratives, multiplicity and heterogeneity, the impossibility of representation and the instability of language are the key terms or phrases used to capture the ideas in women's experimental "feminist-postmodern" (209) fiction. The result is that the novel depicts a narrator who twists and turns on (himself/herself), leaving the reader with the difficult and perhaps impossible task of sorting out product from process, story from narration. Postmodern theory is "usually accompanied by a grand flourish of negativized rhetoric: we hear of discontinuity, disruption, dislocation, decentering, indeterminacy and anti- totalization" (Hutcheon "Beginning" 17). As Deborah Woolley puts it, criticism about postmodern substitutes a heroics of text and language for the older heroics of creative genius and imagination. The text accepts the experimental challenge to confront the lack of a center at the heart of language and to dwell in that void (460). The intricacy of the text, coupled with the apparent failure of the narrator to control and shape the story, forces the reader to construct a meaning for the text and thereby to participate in the construction of the work itself. 
Carol Maso, widely considered to be a distinguished American feminist postmodernist novelist, directly confronts issues of selfhood and authorship. To break out of the male-dominated literary history, Maso has had to discover new ways of telling her story appropriate to her lived experiences. Writing against the received traditions of American literary realism and modernization, against the grand narratives of Western literature, Maso is engaged in the imperative and innovative work of re-visioning and rewriting conventional narrative. In her article: "Rupture, Verge, and Precipice / Precipice, Verge, and Hurt Not," Maso asserts that a marginalized female author should not be asked to adopt and persevere this ideological stance in the construction of her own fiction. Her anticipation is that the contemporary literary community will one day "let the fictions change shape, grow, accommodate" (68). She addresses an imagined patriarchal audience and observes about the nature of conventional literature: "It's been too long now that you've asked me to be you. Insisted I be you" (58). She includes certain suggestions she has for the future of literature: "Wish: That forms other than those you've invented or sanctioned through your thousands of years of privilege might arise and be celebrated" (74). She suggests that she is already realizing in her own experimental novels that endeavor: the novel must be reconstructed through the liberating practice of experimentation. "What is a book", she asks, "and how might it be reimagined, opened up, transformed to accommodate all we've seen, all we've been hurt by, all that's been given, all that's been taken away?" (63). By use of the inclusive term, "we", she recommends this experiential approach to writing to other marginalized (oppressed or subjugated) authors.

The purpose of this paper is to discuss the embodiment of sartrean existentialism in Carol Maso's novel The Art Lover. Her ideology as a novelist has been aligned with the philosophy of existentialism in which she blends the existential notion of freedom with that of postmodernism, creating an opposition between the individual's freedom and responsibility. In the depiction of a world governed by irrational forces of contingency where any cognitive certainty is decentralized, the individual finds himself dislocated and alienated. The prevailing presence of absurdity throughout the whole narrative is a telling of an existential quality much encouraged by Sartre, who believes that it is the individual's responsibility to create his own meaning amidst the meaningless. In fact, existentialism revolves around Sartre's basic question that "whether humans are, or should be, free" (351-57). Existentialism derives from the principle that human behavior is based on nothing except free choice, which marks the struggle between freedom and responsibility (353). In a world dominated by existential chance, novelists are free to choose their own response to the changes created by hazard. "Existential freedom comes through a courageous facing of fear and dread that a recognition of nothingness necessarily evokes" (Oberman 83). Freed from the naive illusionism that the universe operates according to immutable laws which man's rationality is able to discern, the existentialist novelist asserts the independence of the text from the world outside its pages. The problem facing the existential novelist, as Dwight Eddins observes, is that of "reconciling his own ideations with the fortuitousness of existence. In humanizing this world, he lies; in trying not to lie he is threatened by incoherence and chaos" (205). Instead of condemning aesthetic imposition outright and giving up on writing novels, postmodernist strategists fuse experimental writing with narrative conventions in order to draw attention to the novel's fictiveness and to present an ideation which contains contingency, thus portraying reality as the existentialist perceives it.

It could be argued that the condition of uncertainty in Maso's The Art Lover is defined by freedom of choice. Consciousness, a labyrinth of memories and perceptions, paradoxically both creates and is created by choices. Readers who cling to their familiar methods of interpreting texts miss Maso's regenerative gift of uncertainty. At one point in the novel, she writes:

Things are not in our control. One need not look very far to see what I am talking about .... . One loses a certain analytic perspective. I am a lover of detail, a marker-it's a way of keeping the world in place. One documents, makes lists to avoid becoming simply petals. I am like you ... a looker, an accountant, a record keeper, a creator of categories, a documenter. For evidence I rip flyers from telephone poles, save every scrap of paper I get. Listen carefully. Organize. Reorganize.... I am trying to regain my analytic perspective. (12)

Textually, Maso's ambiguity condemns the reader to freedom which, following Sartre's proposition, means readers carry the weight of the text's direction and are largely responsible for establishing an interpretive system. This interpretive work on the part of readers, combined with an openness to re-vision, even though distorted and irrational at times, allows those readers to shift from the role of author, to that of character and thence to that of investigator interchangeably. In one of Maso's interviews, she responded:

What I do know...is that there are many serious, smart, and curious readers out there, and readers who are really starving for alternatives to what There's the mainstream tries to force feed them. been on the part of publishers and writers, I think, a real tendency to condescend to the reader, instead of trusting him or her. (Harris 109)

Maso believes she offers her reading public "a place of creativity and spaciousness and possibility" instead of trying to "dictate or legislate" the reading experience (109). Therefore, Maso maintains, as Steve Moore 
observes "experimentation is redemption," and that" Postmodernism ... implies a kind of hope" (190).

The woman writer is obligated to find alternative techniques for expressing herself authentically. According to Maso, writing in traditional forms is perhaps devastating. The accepted "truth" about how a novel should be, may be the most pressing obstacle for the marginalized writer to overcome. It is a reflection of what Maso has proclaimed in a number of interviews. In "An Interview with Carole Maso," she insists that "a work of literature should be a genuine experience... no (as it most often is) a record of an experience." (186). Victcoria Harris describes Maso's desire to listen to the call of her body:

Carole Maso's writing is somatic, her world a world in which matter matters. When I asked about how she sees her writing as making an intervention into traditional narrative, Maso underscored the physical imperative in her writing, how important it is to her to inscribe the implicatedness of the female body for the female mind. (108)

Unlike the aesthetic productions that characterize many male conventional texts, Maso creates fiction that reflects her existential identity as a female novelist. Conventional literature is not enabling for/relevant to the contemporary woman author, who truly has something to say about her body, her life, and her existential world. Barbara Page explains that the aim of experimental women writers is "to rend the surface of language and to reshape it into forms more hospitable to the historical lives of women and to an esthetic of the will and desire of a self-apprehended female body" (2). Inherent in women's experimental fiction is an implicit understanding of the ways in which women's oppression is encoded in male masculinist? traditional literature:

These women writers, as a rule, take for granted that language itself and much of canonical literature encode hierarchies of value that denigrate and subordinate women, and therefore they incorporate into their work a strategically critical or oppositional posture, as well as a search for alternative forms of composition. (2)

So, women authors, "can produce themselves - as new beings or as ones previously unspoken - through selfconscious acts of writing against received tradition" (1). If women novelists miss the mark to say what they've made a commitment to say, then they can't express themselves genuinely. There is no choice; and this is their existential struggle. And this is exactly what Maso is assuming in The Art Lover.

Maso's narrative techniques is a response to the same existential notions with which The Art Love's story is concerned: the absurdity of reality and the order which people including artists impose on that chaos by means of literary structures and artistic devices. The novel is divided into six (or seven) sections: "Spring 1985, "Summer," "Fall," "Winter," "More Winter," and "Spring 1986," concluding with an "Author's Note," which feels more like a seventh section than something apart from the text. The novel tells the story of an author, Caroline Chrysler, who is in the middle of writing a novel and who is heartbroken about the death of her father-Max. In both her own narrative and the embedded narrative of her doubly-fictionalized novel, the reader is presented with Caroline's existential struggles to confront the issues of her life and to create some kind of meaning out of the life and death of her father. She writes: "I think of the family of father and mother, of two daughters... just a word picture for now"(). She questions it is ever possible to overcome the crisis of losing a family member: "One checks oneself as often as possible, but death still whispers in my father's car in the form of a beautiful woman just about my age. But death is not a beautiful woman. One wants not to have to struggle so much. For all I know he will never ascend into heaven" (15).

The embedded narrative of Caroline's novel also depicts a family in crisis, though it deals with a different kind of absence. In this latter narrative, the father character, Henry, is absent from that family because of his extramarital affair. The mother, Maggie, and her two daughters, Candace and Allison, must deal with Henry's betrayal and accept his paternal absence. They must survive and reconstruct their lives after that loss. Hence, Caroline distills something of her own fictional life into her fictional narrative and, by this "doubling" process, the production of fictional discourse is investigated and brought to the fore. She says: "I am going to write now. It is a way of telling the truth. Or nearing the truth. The absolute truth? The literal truth? Well, yes. Well, no. But something of the whole. Something of what it means to be alive" (15).

The process by which authors distill their own lives into their artistic creations is evident in in both the main and the embedded narratives. At the level of the narrative in Caroline's novel, the characters engage in many of the activities that Caroline is engaged in, say things that replicate Caroline's own conversations with her father Max and her best friend Steven, and concern themselves with the issues and questions Caroline has relating to life and art. For example, she writes: "Max, it is time for wild leeks in West Virginia. Mustard seed in the Napa Valley. Sorrel in New York. You taught me all this. It's time for fiddleheads, those tender shoots of the ostrich farm in Western Massachusetts. I think of death breaking like a star in your head"(15). The burden that life imposes upon Caroline to make a real and reliable presence in the text of her novel is apparent. Caroline has to say "Max, stay out of this" (54). Moreover, all of the characters, at both levels of narration, spend summers in or near Cummington. The fictional family in Caroline's novel spends time in a cottage there; Caroline joins the artists' colony there; even Carole Maso - the actual author of the text - spent time as an artist-in-residence there during the writing of The Art Lover. She once more says: "I am going to write now, because I am a writer. I have already written one 
novel, published when I was twenty. I have seen it turned into a movie, have won several prestigious awards. I have just returned from an artist colony at the edge of the Berkshires. I went for a month, but I stayed for a year. I tried to write poetry" (21). Throughout the novel, any of the various levels of narration bleed through to the other levels.

Furthermore, characters sometimes exhibit a certain amount of existential awareness about an extra-textual reality outside of their existence and their world. At one point, Maggie, the mother in Caroline's novel, shows an awareness of the other levels of narration -- the other worlds she might inhabit -- and questions the setting she is written into:

Someone has rendered each detail with such exactness and precision, the curl on the young girl's brow, the neck of the man, the gentians at their feet. The question in my mind persists. It remains as each one comes closer now. What is the unifying motive here? (17)

After recognizing that there is another reality "out there" and that the desire to obtain true self knowledge is absurd, characters experience the anxiety of freedom and realize that they have free will only insofar as they choose to act. These characters want a reprieve from their secret fears, from the evolving pressures of uncertainty, from what Lois Tyson calls "existential subjectivity" (8). Tyson defines this term as the anxieties of consciousness that come in the form of unanswerable questions such as what will happen and why. In Carol Maso's novel each character's attempts to evade a false move, a hopeless gesture or an error in judgment prove destructive. Freedom is so vast it can be terrifying. Maggie questions the motivative and the meaning? Caroline, and arguably Maso, discovers that nobody can make sense of life, and art is not really meant to order the chaos of life.

The structure of Maso's fiction depends largely on congruence. The discrete narrative worlds in the fiction run in parallel once more when a major character in each narrative is seen to be seeking her father. Caroline, the fictional author in the main narrative, writes about Candace, a daughter of the family in her novel (the embedded narrative) looking for her father Henry, who has abandoned the family for his mistress. Meanwhile, in the outer narrative, Caroline is "looking for" her own father Max, who suddenly died from a heart attack while she was away in Cummington. She morns his death: "Had I not seen his death in the form of the rising sun everywhere, I might have stayed forever. Because it is too early for peach picking in Western Georgia"(12).Caroline finds it hard to come to terms with her father's death and spends a good part of the novel, not only in mourning, but also in search of who he really was, what his life was made of, and what his motivations and beliefs were. Meanwhile, Candace is mourning the "loss" of her father and searching for the reasons why her father left her family. Both daughters, then, are in search of ways in which to cope with their absent fathers.

Moreover, while Caroline is writing this section about Candace, her own father's life intervenes. The doublyfictional Candace locates her father, Henry, in New York City, where he is living with an aspiring actress, Biddy (54). This reflects a facet of Caroline's father's life. Max, before he died, had started a relationship with a young actress also named Biddy. Thus it may be seen that neither Caroline, the fictional author in the text, nor Maso, the "real-world" author purportedly outside the text, can contain their characters in their respective narrative worlds. Candace tries to reconcile the frustrations and anger she has towards her own father. However, Caroline has to say thins to her father, and, within the embedded novel, Candace starts to say things in this section that Max would say. Life becomes absurd, not orderly.

Caroline insists that her multi-narratives have mass, and fluid reality, like the producing body itself: "I've got to feel flesh, bone, hair, earth, somehow in words. The urgency of flesh, bone, hair. The thousand demands of blood" (73). Her responsibility as a writer is not to ignore the demands of her reality but to embrace and transliterate them for the reader. Caroline ultimately acknowledges the obligation and acts upon it to inject her "real life" into her work. To this end, she offers glimpses of her life throughout the text through the almost documentary/intertextual inclusion of various clips of art textbooks, newspaper articles, art reproductions and reprints, photos, and brochures. She announces: "I wanted to make documentaries. I wanted to gather evidence. I wanted to record the truth. What the bums were saying. I rode the subways alone all night, filming" (27). She does this, in part, to include the reader or give the reader an idea of what life might have been like for a woman writer in New York City in the mid-1980s. Caroline is seen to realize that the conventional novel cannot accommodate the needs of the contemporary woman writer - in particular her need to say something authentic about her life. "To think you could have complete control... there's something to it. All these things I've collected: directions, maps, photographs, all kinds of odd scraps.... I've kept everything. Like it might come in handy someday." She adds "Maybe it's a way of having a private life, a life of my own. One no one else could possibly get to or decode.... my passion for documentation" (27). Caroline is seen to realize that the purpose of writing, or art in general, is to provide the artist with a vehicle for expressing her own existential reality, in the form of personal truths: "I am going to write now. It is a way of telling the truth. Or nearing the truth. The absolute truth? The literal truth? Well, yes. Well, no. But something of the whole. Something of what it means to be alive(16-15) ". What the fictional Caroline is proposing here is the notion that art or writing can estimated what the truth is or was for her. But art can be a deeply personal expression of any artist's existential reality. 
The contemporary postmodern text affords the writer a space in which to reveal the existential truth of experience, particularly from a marginalized position. When a young emerging novelist Caroline meets at an artist colony asks her what conditions are necessary in order for a person to take on the task of writing a novel, she addresses, in a sense, the import of having postmodern techniques at her disposal: "First," I tell him, "You must make a commitment like love to it," I say. And I can't do that right now. "Second, you must have something to say." I realize it's starting to sound like a lecture. "But maybe most importantly you must have a way to say it" (68). Maso understands that the conventional novel cannot authentically represent life, since it attempts to impose an artificial order on chaotic lived experience. In this way, the conventional novel is deceptive. In her article "A Novel of Thank You," Maso explains, "Everybody's life is full of stories; your life is full of stories; my life is full of stories. They are very occupying, but they are not very interesting" (102). It seems that Maso is tired of deception and inserts herself in the novel to give a credible impression of her existential reality. She claims that "because we no longer believe that the traditional stories are true, we can no longer write tidy, beginning - middle - end fiction" (Page 8).

In creating her version of existential reality, Maso emerges as a character named Carole in the fifth section of the novel titled "More Winter." It is in this section of the text that Carole, supposedly representing the author Carole Maso, reveals that she is in the middle of dealing with the death of her best friend Gary who has succumbed to the AIDS virus. It is seemingly an autobiographical section. In the other overtly "transgressive" section, "Author's Note," Maso includes a picture of herself with her friend Gary Falk and crosses a sacred narrative boundary in revealing herself in the text. "In the end" she writes, "I was hands to him. The last thing I ever heard him say was, "Are these Carole's hands? My hands on his hands" (243) Furthermore, throughout the text, she includes reprints of actual paintings by Gary Falk, alongside other extratextual materials, something readers are unaware of until they read the "Credits" section. Obviously, most readers are suspicious of the presence of the author in a text that is represented as fictional, but postmodern writing techniques permit the author able to "really" appear in the text as herself. Hence, Maso includes a "Credits" section, a bibliography at the end of the text to prove that the various extratextual materials in the novel are real; are from authentic sources. As long as the stakeholders in the text (the novelist, the characters, the reader) are capable of acting freely, then the novel can come alive. Maso's foremost concern is to carve out a space for herself where she can tell the "truth" of her lived experience as a woman and an author.

Readers are forced to face this narrative practice of interposed extratextual sources on nearly every page of The Art Lover. It is Maso's own world that is constantly incorporated into the body of the text. Those clips are not from Caroline's life in New York City; they are from Maso's. One instance of her several actual presences of "real world" elements in her text is a reprint of the Vermeer painting "Head of a Young Girl" as it appeared in a study of Vermeer, a critical study by Edward Snow. "IT IS ALWAYS" Maso reflects "the beauty of this portrait head-its purity, freshness, radiance, sensuality-that is singled out for comment. Vermeer himself, as Gowing notes, provides the metaphor: she is like a pearl." Maso, by this existential element, offers the reader a chance to experience the painting as the characters (and Maso herself) contemplate it. "It is $m e$ at whom she gazes, with real, unguarded human emotions, and with an erotic intensity that demands something just as real and human in return. The relationship may be only with an image, yet it involves all that art is supposed to keep at bay" (58). She includes with the image Snow's critical commentary in which he underscores the power of the painting to move the viewer:

Faced with an expression that seems always to have already elicited our response, that not only seeks out but appropriates and inhabits our gaze, we can scarcely separate what is visible on the canvas from what happens inside of us as we look. Indeed, it seems the essence of the image at it. to subvert the distance between seeing and feeling, to deny the whole vocabulary of "objective" and "subjective." And yet few paintings give their viewer such a feeling of being held accountable. (qtd. in Maso 58)

In his analysis, Snow describes Vermeer's ability to convey the "objective" and "subjective" as useless signifiers. The viewer is always already viewer and participant. The viewer is the girl in the painting, or rather the viewer is both observer and subject. The painting itself has the ability to make the viewer feel as though her expression is a reaction to the onlooker (the viewer). In Vermeer's painting, as in The Art Lover, there is no formal distancing. The viewer/reader takes a participatory role. Maso's novel also becomes a "didactic genre" (Stirling 587). This is precisely the effect of Maso's reproduction of the painting in her text. "Like Woolf, Maso has found an innovative way to see, like a laser, into the human heart" (qtd. in Dukes 253). For Maso asserts that her readers should accept some existential responsibility and "a feeling of being held accountable," a dynamic role in experiencing the text (58). The indeterminacy is a perfect space for the reader to enter the text. Postmodern novel does not have to result in estrangement and utter confusion for the reader.

Throughout the novel, Maso's existentialist perspective is maintained in the space created by the indeterminacy of the narration. Maso seems to make a more general point about the limitations of conventional narrative. Maso masquerades as a realist, omniscient, intrusive female narrator, even whilst undermining that 
narrator's attempt to convince the reader that the characters actually lived and that their story is historically authentic. Robert Alter sums up this "device" of the naïve but exposed narrator perfectly: "Its purpose is ...to flaunt 'naïve' narrative devices, rescuing their usability by exposing their contrivance, working them into a highly patterned narration which reminds us that all representations of reality are necessarily stylizations" (30). This kind of postmodern narrator is literally a "reality check". The female narrator constantly vacillates between a firm conventional insistence on the authenticity of her tale and an equally firm insistence that the tale is, after all a product of her imagination. This conflict appears most notably in the spectacle of a narrator who theoretically knows what has happened to her characters - after all, it is real - but who also depicts herself as creating that existential reality as he goes along. This existential realism, to which Maso has her narrator adhere, embodies on an aesthetic level. At one point in the novel. We read:

Writing too can keep the world at a distance. One uses "one" instead of "I." One does not look long enough, or one becomes frightened, fainthearted. One turns flesh too often into words on a page .... The temptation is to make it beautiful or perfect or have it make sense. The temptation is to control things, to make something to help ease the difficulty. One checks oneself as often as possible. (26)

Caroline's own recognition that a universal chaos looms behind the fragile structure of human order. It embodies the existential notion that reality is an absurd chaos of ceaseless flux upon which the human subject imposes a highly individuated conception of order.

In conclusion, through her novel The Art Lover, Maso calls attention to the ways in which writers construct mimetic fictions, imitations of life, to represent existential reality. She thus provides a means by which marginalized female authors can emancipate the boundaries of fiction and the stereotypical identities /realities created for them throughout literary history. In "Precious, Disappearing Thíngs," Maso explains that her "distrust of the inherited, patriarchal forms" led her to search for "more feminine shapes- less 'logical' perhaps, since a terrible logic had brought us here" (66-7). It is also a call to reread predetermined notions of a centered identity and accepted reality. Moreover, Maso thinks "it's women themselves who need to be encouraged not to be afraid, who need to give themselves permission to get lost...to really dream and insist on their dreams, their bodies, everything. Men feel the right to do anything. themselves those freedoms' (188). She offers her readers an exercise in escaping the boundaries of textual reality and invites them to test her theories of the constructed nature of existential reality in their own lives, in order to provide some existential freedom in creating realities that are more appropriate to their lives. She affords readers a chance to interact with the text and the author by disposing of the prescribed roles of reader, author, and text. One question threaded through the text of The Art Lover is that of whether, given the concrete reality of the words and images on its pages, any freedom of choice really exists. Maso presents consciousness as something pursued but not necessarily caught.

\section{References}

1) Alter, Robert. Partial Magic. Berkeley: University of California Press, 1975:30.

2) Dukes, Carol Muske ."The Picture Gallery of the Heart: The Art Lover by Carole Maso." North Point Press July 1 (1990: 253). Phttps://www.latimes.com/archives/la-xpm-1990-07-01-bk-720-story.html

3) Eddins, Dwight. "John Fowles: Existence as Authorship." Contemporary Literature 17.2 (1976): 204-222.

4) Harris, Victoria Frankel. "Carole Maso: An Introduction and an Interpellated Interview." The Review of Contemporary Fiction 17 (1997):104-111.

5) Hutcheon, Linda. "Beginning to theorize postmodernism." Textual Practice 1.1 (1987): 10-31.

6) Lodge, David. The Modes of Modern Writing. Ithaca: Cornell University Press, 1977: 226.

7) Maso, Carole. The Art Lover. Hopewell, NJ: ECCO,1990.

8) ---. "A Novel of Thank You." Break Every Rule, DA.C.: Counterpoint, 2000: 72-104.

9) ---. "Precious, Disappearing Thíngs." Break Every Rule, DA.C.: Counterpoint, 2000: 64-71.

10) --- . "Rupture, Verge, and Precipice / Precipice, Verge, and Hurt Not." The Review of Contemporary Fiction 16.1(1996):54-76

11) Michael, Magali Cornier, and Margaret Atwood. Feminism and the Postmodern Impulse: Post-World War II Fiction. Suny Press, 1996.

12) Moore, Steven. "An Interview with Carole Maso." The Review of Contemporary Fiction 14 (1994):166-91.

13) Oberman, Warren Scott. Existentialism and postmodernism: Toward a postmodern humanism. The University of Wisconsin-Madison, 2001.

14) Page, Barbara. "Women Writers and the Restive Text: Feminism, Experimental Writing and Hypertext." Postmodern Culture 6(1996):1-29.

15) Stirling, Grant, and Carole Maso. "Mourning and Metafiction: Carole Maso's 'The Art Lover.", Contemporary Literature, vol. 39, no. 4, [Board of Regents of the University of Wisconsin System, University of Wisconsin Press], 1998, pp. 586-613, https://doi.org/10.2307/1208727.

16) Sartre, Jean-Paul. Existentialism and Human Emotions. 1957. Trans. Bernard Frechtman and Hazel E. Barnes. 
New York: Philosophical Libraries, 1985.

17) Woolley, Deborah A. "Empty 'Text' Fecund Voice: Self-Reflexivity in Barth's Lost in the Fun House." Contemporary Literature 26.4 (1985:460-81).

18) Tyson, Lois. "Existential Subjectivity on Trial: The Crying Lot 49 and Politics of Despair." Pynchon Notes 28-29 (1991):5-26. 